\title{
Women and Corruption
}

\author{
Elmira Akhmetova*
}

Transparency International, the global coalition against corruption, defines corruption as "the abuse of entrusted power for private gain. It hurts everyone who depends on the integrity of people in a position of authority." Corruption has a devastating impact on the social, economic, ethical and mental wellbeing of human beings as an individual and community. In Islam, any form of corruption ( fas $\bar{a} d$ ) like bribery, extortion, kickback and illegal gratuity are strictly prohibited by the texts. The Qur'ān enjoins the believers not to consume their property among themselves unjustly and not to give bribes to the rulers that may sinfully and knowingly lead to devouring of the property of others (al-Baqarah 2:188). In several other verses, the text also condemns all forms of economic and political oppression and proscribes spreading of mischief and corruption on the earth (alQașaș 28:4 and al-A'räf 7:56). The Prophet Muhammad (peace be upon him) has said that the bribe-taker, the bribe-giver and their mediator, all of them invoke God's wrath.

Hence confronting bribery, corruption and other types of social illnesses, and creating a fair and righteous society are integral parts of Islamic teachings. ${ }^{2}$ Yet Transparency International's Corruption Perceptions Index (CPI), ranked many Muslim countries as having the highest perceived levels of corruption in the world. The latest Index in 2013 scored 177 countries and territories on a scale from 0 (highly corrupt) to 100 (very clean). In that list, the ten bottom countries which were ranked as most corrupt, excluding North Korea, are Muslim-majority countries. Somalia and Afghanistan, along with non-Muslim North Korea, made up the worst performers in the year, scoring just 8 points each. It is followed by Sudan (11 points), South Sudan (14 points), Libya (15 points), Iraq (16 points), Uzbekistan, Turkmenistan and Syria (17 points each). Only three Muslimmajority countries score above 50: United Arab Emirates, Qatar and Brunei (69, 68 and 60 points respectively).

These results warn that the abuse of power, secret dealings and bribery wreck personal and public wellbeing in the Muslim world. In addition, most of the bottomline countries in the Index 2013 which are ranked as having the highest level of corruption are suffering from long-lasting wars, armed conflicts and severe poverty. Hence, the level of corruption is clearly related to the degree of human security and stability in that particular region. Without providing basic safety and essential human necessities to the public, anti-corruption campaigns alone may not be able to produce good results; and vice versa, good governance, transparency and human security are non-achievable in a corrupt society. 
Corruption is not gender neutral; women are more disadvantaged from the consequences of a corrupt system. Since women often face cultural, social, economic and political discrimination in their daily lives, they encounter even more distress and social exclusion in a corruption-ridden society. Roslyn G. Hees, Senior Advisor at Transparency International, observed that a corrupt legal system reinforces existing gender discrimination in many countries. Women`s civil rights are grossly unfair with regard to marriage/divorce, family law, child custody, financial independence, inheritance and property rights. They are often unable to make decisions without the consent of a male relative. ${ }^{3}$ In many countries, corrupt judicial procedures and the prevalence of nepotism and gender discrimination makes it in the majority of cases impossible for women to win lawsuits in a transparent and open way. Therefore, Transparency International strongly recommends that anti-corruption measures need to be gender responsive to facilitate gender equity and women's empowerment. ${ }^{4}$ Recent studies have shown that empowered women who have an opportunity to participate in decisionmaking are powerful actors who can contribute to the fight against corruption.

A study by the IRIS Centre, University of Maryland, observed that higher levels of women's participation in public life are associated with lower levels of corruption. This cross-country data revealed that corruption is less severe where women comprise a larger share of the labour force, and where women hold a larger share of parliamentary seats. ${ }^{5}$ Another influential study produced by the World Bank in 1999, entitled "Are Women Really the 'Fairer' Sex? Corruption and Women in Government," also suggested that higher rates of female participation in government are associated with lower levels of corruption. After studying 150 countries in Europe, Africa and Asia, the researchers came to the conclusion that women are more trustworthy and less prone to corruption. It consequently suggested that women may have higher standards of ethical behaviour and appear to be more concerned with the common good. ${ }^{6}$

During his visit to International Institute of Advanced Islamic Studies (IAIS) Malaysia on $10^{\text {th }}$ December 2013 H.E. Abdul Salam Azimi, the Chief Justice of Afghanistan and the head of the Afghan Supreme Court, confirmed that women in Afghanistan are less prone to corruption. There are more than 180 female judges in Afghanistan today, which constitutes approximately 10 per cent of total Afghan judges ( 5 years ago it was 3 per cent). According to Azimi there has not been even a single case of corruption with these female judges in the face of the high level of corruption in the existing Afghan judiciary overall. Chief Justice Azimi consequently intends to assign more female judges in order to lessen the endemic of corruption in Afghan society. However, the appointment of female judges in the provinces is still extremely challenging due to reasons of safety, economic and social customs. At present ten female judges are based in Balkh, 
five in Herat, two each in Takhar and Baghlan, with the rest based in Kabul. But the presence of female judges in all courtrooms of the country is highly essential for two reasons. Firstly, as has been articulated above, female judges are perceived as less corrupt. Secondly, if a woman judge is present in a province, a woman complainant can share her problems with full confidence while she may not feel easy to share them with a judge.

A similar approach to gender attentive distribution of power is intended to expand to other segments of the Afghan government. The Lower House of Parliament (Wolesi Jirga), which holds the power to enact, amend and repeal laws, has 69 women members out of a total 249 delegates ( 27.7 per cent), emerging as the $37^{\text {th }}$ country with the largest female participation in legislature out of 189 countries in the world. Other countries scored as follows in 2013: Germany (32.9 per cent), France (26.9 per cent), UK (22.5 per cent), Turkey (14.2 per cent), Russia (13.6 per cent), Malaysia (10 per cent), Iran (3per cent) and Egypt ( 2 per cent). In the long run, it is believed that the engagement of women in Afghan leadership as decisionmakers and role models might bring peace, harmony and betterment to Afghan society which has been suffering from years of conflict and destructive wars.

In fact, the policy of gender attentive distribution of power has previously succeeded in the Republic of Rwanda, the first country to have a majority of women in its legislature since their 2008 election. Rwanda does not have spectacular gender equality in other aspects of society, but radically increased its female leadership due to severe national conflict and violence. After the genocide that killed approximately 800,000 Tutsis in 1994, the Rwandan legislature went from 18 per cent women before the conflict to 56 per cent in 2008 . Rwanda today has low corruption and fewer conflicts compared with its neighbouring countries. Rankings made by the World Bank over the last ten years show that Rwanda has made considerable progress from 20 per cent in 1996 to 70.8 per cent in 2010, emerging as the fourth $\left(4^{\text {th }}\right)$ least corrupt country out of 53 countries in Africa after Botswana (79.9 per cent), Cape Verde (74.6 per cent) and Mauritius (73.2 per cent). According to Transparency International, over the period of 2006 to 2011 corruption has declined from 2.5 out of 10 in 2006 to 5.0 in 2011, showing the most improvment in the East African region. East African countries scored as follows in 2011: Rwanda (5.0), Burundi (1.9), Kenya (2.2), Uganda (2.4) and Tanzania (3.0)..$^{7}$ No doubt many factors played fundamental roles in curbing corruption, violence and crime in Rwanda; but the active participation of women in law and policy-making processes could be considered as one of the principal explanations for the Rwandan success.

Since women in positions of power are perceived as less corrupt and more honest, active participation of women in law-making and the public sphere is essential. Needless to say, better educated and informed women are better 
empowered to fight against corruption, injustice and dishonesty. To observe the correlation between women's active participation in public life and wellbeing of the society merits greater research effort. In the Muslim world in particular, which suffers from the evils of corruption most, the rights of women to education and work should not be marginalised. Religious leaders, scholars and judges could play an important role in the betterment of Muslim countries through public condemnation of all types of corruption, cheating and bribery, as well as empowering the status of women in their societies.

\section{Notes}

* Elmira Akhmetova, a Tatar scholar from Russia, is Research Fellow at IAIS Malaysia. She has published a number of academic articles, book chapters and monographs on the issues of Islamic history, interfaith dialogue, Islamic political thought and civilisational studies.

1. http://www.transparency.org/whatwedo?gclid=CMzgvZqGy7wCFawB4godzV wAxw, accessed 20 February 2014.

2. See Mohammad H Kamali, "Bribery and Corruption from a Shariah Perspective," Islam and Civilisational Renewal, vol.4, no. 2 (April 2013), 295-297.

3. http://www.transparency.org/news/pres srelease/gender_and_corruption_are_ women_less_corrupt, accessed 18 February 2014.

4. http://www.anti-corruption.org/index.php/en/themes/anti-corruption-women-sempowerment, accessed 18 February 2014.

5. Swamy, Knack, Lee and Azfar, "Gender and Corruption," IRIS Centre Working Paper No. 232, (1999), 19.

6. David Dollar et al, "Are Women Really the Fairer Sex? Corruption and Women in Government", World Bank

7. Working Paper Series No. 4 (1999); and http://www-wds.worldbank.org/servlet/ WDSContentServer/WDSP/IB/2000/08/26/000094946_0008120532266/ Rendered/PDF/multi_page.pdf, accessed 7 March 2014.

8. "Rwanda Anti-Corruption Policy," Office of the Ombudsman, http://ombudsman. gov.rw/IMG/pdf/rwanda_anti_corruption_policy.pdf, accessed 7 March 2014. 